\title{
Effect of Storage Conditions and Scarification on in vitro Seed Germination in Lorathus tanakae Hosok
}

\author{
Amal Kumar Ghimeray ${ }^{1}$, Hyun Woo Lee ${ }^{1}$, Bo-Duk Lee ${ }^{1}$, Pankaja Sharma ${ }^{1}$, \\ Ie Sung Shim ${ }^{2}$ and Cheol Ho Park ${ }^{1 *}$ \\ ${ }^{1}$ Department of Bio-health Technology, Kangwon National University, Chuncheon 200-701, Korea. \\ ${ }^{2}$ Departments of Horticulture, Seoul City University, Seoul 130-743, Korea
}

\begin{abstract}
Loranthus tanakae (Franch. \& Sav.) is an endangered species of mistletoe, distributed in Korean peninsula. The objective of our research is to determine the effect of storage duration and conditions [air flow (AF) and air tight (AT)] at different temperatures for survivability and germination of mistletoe seeds, and also to monitor the effect of seed scarification on germination in vitro. The result revealed that the seeds stored in natural conditions (no stratification) showed highest survival rate of $100 \%$ and retained up to $93.3 \%$ even after two months of storage in natural conditions and showed higher germination percentage $(90 \%)$ compare to after ripened seeds. However, the seed stored at $0^{\circ} \mathrm{C}$ decreased the germination percentage (ranged from 63 to 73\%). Therefore, it can be confirmed that mistletoe does not need after ripened treatment to promote germination. Our research also showed that the storage of L. tanaka seeds in freezing temperatures of $-20^{\circ} \mathrm{C}$ and in room temperature for long time either in AT or AF conditions caused the loss of survival and germination rate. On the other hand, the chemical scarification $\left(0.01 \mathrm{~N} \mathrm{HCl}\right.$ incubation for $12 \mathrm{hrs}$. at $\left.38^{\circ} \mathrm{C}\right)$ method was proven more effective to enhance germination percentage of L. tanakae. Regarding the temperature regime, $22^{\circ} \mathrm{C}$ showed early germination of mistletoe seeds in vitro.
\end{abstract}

Key words - Endangered species, Stratification, Scarification, Loranthus tanakae, Germination

\section{Introduction}

Loranthus tanakae (Franch. \& Sav.) Hosok. a species of mistletoe, synonymously called Hyphear tanakae Hosokawa, is a semi-parasitic, deciduous shrub of Loranthaceae family that grows on the branches or twigs of trees and is distributed in Korean peninsula and China (Huaxing et al., 2003). The plant is considered as an endangered species and grows in different host plants like Quercus, Prunus, Morus and also in Poppulus species (Kim et al., 2013; Lee 2010b). It develops a special structure called haustorium which penetrates into the phloem tissue of the host plan to absorb water and nutrients (Kim et al., 2013; Calvin and Wilson 1998; Lee et al., 2009). It is considered as a medicinal plant as it is known to produce variety of bioactive compounds (quercetin glycosides, kaempferol glycosides, etc) which have significant anti-tumor properties (Kim et al., 2004).

*Corresponding author. E-mail : chpark@kangwon.ac.kr
In Korea, the leaves, twigs and stem of mistletoe are used traditionally to make herbal medicine. A decoction of leaves and stem consumed traditionally is believed to cure number of ailments, including immune stimulation. However, due to over exploitation, the plant became endangered. Therefore, this research aims to restore its population and multiplication of plant by ex-situ method. For that, here we studied the survivability and germination of mistletoe seeds after harvest, and the effect of storage duration and conditions (air flow and air tight) at different temperatures were determined. We also examined the effect of seed scarification on mistletoe seed germination in vitro.

\section{Materials and methods}

\section{Sample collection}

Mature mistletoe (Loranthus tanakae) plants with yellow fruits in a dark brown stem, grown in the oak trees in natural habitat were harvested in $2^{\text {nd }}$ week of Nov. 2013 from Yuljeon-ri, 
Korean J. Plant Res. 27(3) : 263 270 (2014)

Hongcheon-gun, Gangwon-do (37.74N, 128.32E), Korea.

\section{Storage conditions of mistletoe seeds at different temperatures}

After harvesting, mistletoe fruits were separated from the stem which was considered as non-after-ripened seeds and subjected to germination test (total 30 seeds in 3 replications). Remaining fruits were stored at different temperatures (-20, $0,+4$ and room temperature $\left(22 \pm 2^{\circ} \mathrm{C}\right)$ in air tight (AT) or air flow (AF) conditions for one and two months duration (considered as after-ripened). Other fruits were preserved in a natural environment for two months to compare the germination pattern with stratified seeds.

\section{Chemical and Mechanical scarification of seed}

In chemical scarification method, 30 seeds (without pulp) in three replications were scarified by immerging in $0.01 \mathrm{~N}$ $\mathrm{HCl}$ of appropriate volume and incubated at a constant temperature of $38^{\circ} \mathrm{C}$ for $12 \mathrm{hrs}$. In mechanical scarification, seeds were placed on sterilized river sand moistened with distilled water in a plastic container and rotated gently for $2 \mathrm{hrs}$. After scarification, the seeds were incubated at $38^{\circ} \mathrm{C}$ for $12 \mathrm{hrs}$. The unscarified seeds were taken as a control. After the completion of incubation time, the scarified and unscarified seeds were subjected to germination test after sterilization.

\section{Sterilization of mistletoe seeds and germination test}

The pulp of fruits (non-after ripened or after ripened) were removed manually by rubbing them against paper towel. Next, the seeds were washed in running water and dried in paper towel. To avoid contamination from microorganisms, 30 seeds were washed by immersing in $50 \mathrm{ml}$ of sodium hypochlorite solution (1.5\%) for $3 \mathrm{~min}$ and were shaken vigorously. They were then washed with six changes of distilled water. Another 30 seeds were washed only with distilled water for six changes which served as control. After draining out the liquid of the final wash, three replications of 30 seeds were placed on absorbent paper that had been moistened with distilled water in Petri dishes $(9-\mathrm{cm})$. The petri dishes were then placed at two different temperature $\left(15^{\circ} \mathrm{C}\right.$ and $\left.22^{\circ} \mathrm{C}\right)$ regimes in germinator under $16 / 8 \mathrm{hrs}$ photoperiod with $80 \%$ relative humidity. During the germination period, petri dishes were watered with distilled water as per need to ensure adequate moisture for seed germination. The seeds in the dishes were maintained for germination with close observation. After 4 weeks, the germination percentage of each treatment was calculated from the average of 3 replications' percentage. The survivability of the seeds was also evaluated every week by counting the remaining individuals whose seed coat color were not changed from green to brown.

\section{Statistical analysis}

The data on germination (\%) and survival rate (\%) were analysed using ANOVA. The treatment means were tested by the Tukey tests at the $5 \%$ level of significance.

\section{Results}

\section{Survival rate of seeds during in vitro germination process}

The temperatures at which the seeds were stored had a marked influence on the survivability of mistletoe. According to the data observed after 28 days, the freshly harvested seeds when allowed to germinate in Petri dish showed the highest survival rate up to $100 \%$ (one month) and retained up to $93.3 \%$ even after two months of storage in natural conditions (Table 1 and 2). The survival rates of seeds stored for one and two months were not significantly different with the seeds stored at $0^{\circ} \mathrm{C}$ either in $\mathrm{AT}$ or AF conditions, where the survival rate ranged from 80 to $90 \%$ at 15 and $22^{\circ} \mathrm{C}$ germinator.

The seeds stored at $4^{\circ} \mathrm{C}$ also showed higher rate of survivability (observed in a germinator at $15^{\circ} \mathrm{C}$ ) with $93.3 \%$ (one month stored) and $80 \%$ (two months stored) in $\mathrm{AF}$ conditions. In the same conditions, the survivability rates were 83.3 and $87 \%$ respectively for the one and two months stored seeds at $22^{\circ} \mathrm{C}$ germinator. In the AT condition, 80 (one month stored) and $73.3 \%$ (two months stored) survivability was observed at $15^{\circ} \mathrm{C}$ germinator and 83.3 (one month stored) and $76.7 \%$ (two month stored) survivability were observed at $22^{\circ} \mathrm{C}$ germinator. The one month stored seeds at room temperature in AF condition showed 50 and $73.3 \%$ survivability when tested in a germinator at 15 and $22^{\circ} \mathrm{C}$ respectively. However, $0 \%$ percentage survivability was observed in the seeds stored for one month in AT condition and also in the seeds stored for two months in both AF and AT conditions. The after-ripened seeds stored at $-20^{\circ} \mathrm{C}$ for a month in $\mathrm{AF}$ 
Table 1. Survival rate of 1 month stored mistletoe seeds in different temperature and conditions as determined by germination test at 15 and $22^{\circ} \mathrm{C}$

\begin{tabular}{|c|c|c|c|c|c|c|c|}
\hline \multicolumn{8}{|c|}{ Number of seed survived ( $\%$ in parentheses) } \\
\hline Conditions & $\begin{array}{l}\text { Temp. used for } \\
\text { germination }\left({ }^{\circ} \mathrm{C}\right)\end{array}$ & $\begin{array}{l}\text { No. of seeds used } \\
\text { in } 3 \text { replications }\end{array}$ & 7 days & 14 days & 21 days & 28 days & $\begin{array}{c}\text { Total \% of survival } \\
\text { after } 28 \text { days }\end{array}$ \\
\hline \multirow{2}{*}{$\begin{array}{l}\text { Non-after } \\
\text { ripened seeds }\end{array}$} & 15 & 30 & $30(100)$ & $30(100)$ & $30(100)$ & $30(100)$ & $100^{\mathrm{a}}$ \\
\hline & 22 & 30 & $30(100)$ & $30(100)$ & $30(100)$ & $30(100)$ & $100^{\mathrm{a}}$ \\
\hline \multirow{2}{*}{$-20^{\circ} \mathrm{C} \mathrm{AF}$} & 15 & 30 & $4.3(14.3)$ & $3((10)$ & $3(10)$ & $3(10)$ & $10.0^{f}$ \\
\hline & 22 & 30 & $11(36.7)$ & $3(10)$ & $1(3.3)$ & $1(3.3)$ & $3.3^{\mathrm{gh}}$ \\
\hline \multirow{2}{*}{$-20^{\circ} \mathrm{C} \mathrm{AT}$} & 15 & 30 & $3.7(12.3)$ & $3.7(12.3)$ & $2.7(9)$ & $1.7(5.7)$ & $5.6^{\mathrm{fg}}$ \\
\hline & 22 & 30 & $7(23.3)$ & $4(13.3)$ & $3(10)$ & $1(3.3)$ & $3.3^{\mathrm{gh}}$ \\
\hline \multirow{2}{*}{$0^{\circ} \mathrm{C} \mathrm{AF}$} & 15 & 30 & $29.1(97)$ & $27(90)$ & $27(90)$ & $27(90)$ & $90.0^{\mathrm{b}}$ \\
\hline & 22 & 30 & $30(100)$ & $28(93.3)$ & $27(90)$ & $26(86.7)$ & $87.0^{\mathrm{bc}}$ \\
\hline \multirow{2}{*}{$0^{\circ} \mathrm{C}$ AT } & 15 & 30 & $30(100)$ & $27(90)$ & $25(83.3)$ & $25(83.3)$ & $83.3^{\mathrm{c}}$ \\
\hline & 22 & 30 & $30(100)$ & $28(93.3)$ & $27(90)$ & $27(90)$ & $90.0^{\mathrm{b}}$ \\
\hline \multirow{2}{*}{$+4^{\circ} \mathrm{C} \mathrm{AF}$} & 15 & 30 & $30(100)$ & $30(100)$ & $28(93.3)$ & $28(93.3)$ & $93.3^{\mathrm{ab}}$ \\
\hline & 22 & 30 & $28(93.3)$ & $27(90)$ & $26(86.7)$ & $25(83.3)$ & $83.3^{\mathrm{c}}$ \\
\hline \multirow{2}{*}{$+4^{\circ} \mathrm{C} \mathrm{AT}$} & 15 & 30 & $26(86.7)$ & $25(83.3)$ & $25(83.3)$ & $24(80)$ & $80.0^{\mathrm{c}}$ \\
\hline & 22 & 30 & $26(86.7)$ & $26(86.7)$ & $26(86.7)$ & $25(80)$ & $83.3^{\mathrm{c}}$ \\
\hline \multirow{2}{*}{$22 \pm 2^{\circ} \mathrm{C} \mathrm{AF}$} & 15 & 30 & $24(80)$ & $15(50)$ & $15(50)$ & $15(50)$ & $50.0^{\mathrm{e}}$ \\
\hline & 22 & 30 & $24(80)$ & $23(76.7)$ & $23(76.7)$ & $22(73.3)$ & $73.3^{\mathrm{d}}$ \\
\hline $22 \pm 2^{\circ} \mathrm{C}$ & 15 & 30 & $2(6.7)$ & $0(0)$ & $0(0)$ & $0(0)$ & $0.0^{\mathrm{h}}$ \\
\hline AT & 22 & 30 & $3(10)$ & $0(0)$ & $0(0)$ & $0(0)$ & $0.0^{\mathrm{h}}$ \\
\hline
\end{tabular}

Small letters in superscripts represent significant differences at the level of 5\% according to Tukey Test.

Table 2. Survival rate of 2 months stored mistletoe seeds in different temperature and conditions as determined by germination test at 15 and $22^{\circ} \mathrm{C}$

\begin{tabular}{|c|c|c|c|c|c|c|c|}
\hline \multicolumn{8}{|c|}{ Number of seed survived ( $\%$ in parentheses) } \\
\hline Conditions & $\begin{array}{l}\text { Temp. used for } \\
\text { germination }\left({ }^{\circ} \mathrm{C}\right)\end{array}$ & $\begin{array}{l}\text { No. of seeds used } \\
\text { in } 3 \text { replications }\end{array}$ & 7 days & 14 days & 21 days & 28 days & $\begin{array}{c}\text { Total \% of survival } \\
\text { after } 28 \text { days }\end{array}$ \\
\hline \multirow{2}{*}{$\begin{array}{c}\text { Non-after } \\
\text { ripened seeds }\end{array}$} & 15 & 30 & $30(100)$ & $28(93.3)$ & $28(93.3)$ & $28(93.3)$ & $93.3^{\mathrm{a}}$ \\
\hline & 22 & 30 & $30(100)$ & $29(96.7)$ & $28(93.3)$ & $28(93.3)$ & $93.3^{\mathrm{a}}$ \\
\hline \multirow{2}{*}{$-20^{\circ} \mathrm{C} \mathrm{AF}$} & 15 & 30 & $7(23.3)$ & $2(6.7)$ & $1(3.3)$ & $0(0)$ & $0.0^{\mathrm{e}}$ \\
\hline & 22 & 30 & $22(73.3)$ & $12(40)$ & $4(13.3)$ & $2(6.7)$ & $6.7^{\mathrm{d}}$ \\
\hline \multirow{2}{*}{$-20^{\circ} \mathrm{C} \mathrm{AT}$} & 15 & 30 & $10(33.3)$ & $2(6.7)$ & $0(0)$ & $0(0)$ & $0.0^{\mathrm{e}}$ \\
\hline & 22 & 30 & $19(63.3)$ & $7(23.3)$ & $2(6.7)$ & $0(0)$ & $0.0^{\mathrm{e}}$ \\
\hline \multirow{2}{*}{$0^{\circ} \mathrm{C} \mathrm{AF}$} & 15 & 30 & $30(100)$ & $28(93.3)$ & $25(83.3)$ & $25(83.3)$ & $83.3^{\mathrm{b}}$ \\
\hline & 22 & 30 & $30(100)$ & $30(100)$ & $28(93.3)$ & $27(90)$ & $90.0^{\mathrm{a}}$ \\
\hline \multirow[b]{2}{*}{$0^{\circ} \mathrm{C} \mathrm{AT}$} & 15 & 30 & $28(93.3)$ & $25(83.3)$ & $25(83.3)$ & $25(83.3)$ & $83.3^{\mathrm{b}}$ \\
\hline & 22 & 30 & $30(100)$ & $28(93.3)$ & $26(86.7)$ & $24(80)$ & $80.0^{\mathrm{bc}}$ \\
\hline \multirow{2}{*}{$+4^{\circ} \mathrm{C} \mathrm{AF}$} & 15 & 30 & $28(93.3)$ & $28(93.3)$ & $26(86.7)$ & $24(80)$ & $80.0^{\mathrm{bc}}$ \\
\hline & 22 & 30 & $30(100)$ & $29(96.7)$ & $27(90)$ & $26(86.7)$ & $87.0^{\mathrm{ab}}$ \\
\hline \multirow{2}{*}{$+4^{\circ} \mathrm{C} \mathrm{AT}$} & 15 & 30 & $25(83.3)$ & $25(83.3)$ & $24(80)$ & $22(73.3)$ & $73.3^{\mathrm{c}}$ \\
\hline & 22 & 30 & $25(83.3)$ & $25(83.3)$ & $25(83.3)$ & $23(76.7)$ & $76.7^{\mathrm{c}}$ \\
\hline \multirow{2}{*}{$22 \pm 2^{\circ} \mathrm{C} \mathrm{AF}$} & 15 & 30 & $0(0)$ & $0(0)$ & $0(0)$ & $0(0)$ & $0.0^{\mathrm{e}}$ \\
\hline & 22 & 30 & $0(0)$ & $0(0)$ & $0(0)$ & $0(0)$ & $0.0^{\mathrm{e}}$ \\
\hline $22 \pm 2^{\circ} \mathrm{C}$ & 15 & 30 & $0(0)$ & $0(0)$ & $0(0)$ & $0(0)$ & $0.0^{\mathrm{e}}$ \\
\hline AT & 22 & 30 & $0(0)$ & $0(0)$ & $0(0)$ & $0(0)$ & $0.0^{\mathrm{e}}$ \\
\hline
\end{tabular}

Small letters in superscripts represent significant differences at the level of $5 \%$ according to Tukey Test. 
condition showed 10 and $3.3 \%$ survival rate at 15 and $22^{\circ} \mathrm{C}$ germinator respectively. In same condition after two months, nearly $6.7 \%$ seeds retain their survival capacity. At the same temperatures in AT condition, the survival rates were further decreased to 5.6 and $3.3 \%$ at 15 and $22^{\circ} \mathrm{C}$ germinator respectively. Furthermore, the survival rate was decreased to $0 \%$ in the two months stored seeds in AT conditions.

\section{Effect of storage temperatures on germination rate}

The germination tests were performed at two constant temperature regimes of 15 and $22^{\circ} \mathrm{C}$ and the results are shown in Table 3 and 4 . When the total germination of seeds was counted after 28 days, the freshly harvested (non-after-ripened) seeds showed 67 and $70 \%$ germination at 15 and $22^{\circ} \mathrm{C}$ respectively. The mistletoe seeds kept for 2 months in natural condition (as described in method) without any treatment and allowed to germinate at both temperature regimes of 15 and $22^{\circ} \mathrm{C}$ showed higher percentage of germination (90\%). However, the seeds stratified at $0^{\circ} \mathrm{C}$ decreased the germination by $20 \%$. The germination rate of one and two months stored seed at $0^{\circ} \mathrm{C}$ in $\mathrm{AF}$ and $\mathrm{AT}$ conditions were not significantly different, where the germination ranged from 63 to $73 \%$ in the germinator at $15^{\circ} \mathrm{C}$ and $22^{\circ} \mathrm{C}$.

The seeds stored at $4{ }^{\circ} \mathrm{C}$ for one and two months in $\mathrm{AF}$ condition did not show any significant difference in germination, where the percentage ranged from 73 to $77 \%$ at $15^{\circ} \mathrm{C}$ germinator (Table 3 \& 4). However in AT condition, the germination percentage of the seeds stored for two months was reduced to $43.3 \%$ from $57 \%$ of one month stored seeds. Similarly, one and two months stored seeds at $4{ }^{\circ} \mathrm{C}$ also showed a low germination percentage ( 47 to $50 \%$ ) in $22^{\circ} \mathrm{C}$ germinator with no significant difference between the seeds stored in AF and AT conditions. Previously, Lee et al. (2010a) also conducted an in vitro germination test of mistletoe seeds on $4^{\circ} \mathrm{C}$ stored seeds in different growth media (without viscin) where they found $60-69 \%$ of germination in freshly harvested seed, later the germination percent was reduced with increase in storage duration.

The seeds stored for one month in room temperature $\left(22 \pm 2^{\circ} \mathrm{C}\right)$ in AF condition showed 70 and $83.3 \%$ of germination at 15 and $22^{\circ} \mathrm{C}$ germinator respectively within two weeks. However, it was reduced to $0 \%$ germination for the seeds stored for one month in AT condition and also for the seeds stored for two months in both AF and AT conditions. The stratified afterripened seeds stored for one month at $-20^{\circ} \mathrm{C}$ in $\mathrm{AF}$ condition showed 10 and $3 \%$ germination at 15 and $22^{\circ} \mathrm{C}$ germinator respectively. However, the germination was decreased to $0 \%$ with an increase in storage duration for 2 months in AT or AF condition. In another study by Scharpf (1970) in dwarf mistletoe (Arceuthobium abietium and A. occidentale) found that the temperature affected the viability and germination most noticeably. Our results are in agreement with the findings of Scharpf (1970), in which the dwarf mistletoe seeds kept for two months for after-ripened showed significantly lower percentage of germination than did fresh seeds allowed to germinate immediately.

\section{Germination pattem}

The non-after-ripened seeds, after ripened seeds (at -20 and $0^{\circ} \mathrm{C}$ ) and scarified seeds showed significantly different germination pattern when subjected to germinator at two constant temperature regimes of 15 and $22^{\circ} \mathrm{C}$ (Table 3 and 4). The freshly harvested (non-after ripened) seeds started germination within 9 days after placing the seeds in germinator at $22^{\circ} \mathrm{C}$ and reached maximum $43.3 \%$ after two weeks, However, the germination started after 11 days at $15^{\circ} \mathrm{C}$ germinator and showed maximum germination of $30 \%$ after three weeks. On the other hand, the mistletoe seeds which were kept for 2 months in natural condition showed higher percentage of germination (60 and $83.3 \%$ at 15 and $22^{\circ} \mathrm{C}$ respectively) within two weeks.

The $0^{\circ} \mathrm{C}$ stratified seeds kept for a month in AF and AT conditions showed maximum germination of $46.7 \& 36.7 \%$ respectively within three weeks at $15^{\circ} \mathrm{C}$ germinator. However, at $22^{\circ} \mathrm{C}$ germinator, the rate was $40 \& 33.3 \%$ in $\mathrm{AF}$ and $\mathrm{AT}$ conditions respectively within two weeks. Similar trends of germination were observed for the 2 months stratified seeds at $0^{\circ} \mathrm{C}$ where the seeds were germinated maximum within 2 to 3 weeks in the range of 30 to $53.3 \%$.

With $4^{\circ} \mathrm{C}$ stratification, the one month stored seeds showed early commencement (after 5 days) of germination which was in the range of 10 to $23.3 \%$ within a week. The maximum germination rate was recorded in a germinator at $15^{\circ} \mathrm{C}$ within 2 weeks with $53.3 \%$ in AF conditions, while germination at the $22^{\circ} \mathrm{C}$ germinator was found maximum $30 \%$ in AT after 2 
Table 3. Germination rate of 1 month stored mistletoe seeds in different temperature and conditions as determined by germination test at 15 and $22^{\circ} \mathrm{C}$

\begin{tabular}{|c|c|c|c|c|c|c|c|c|}
\hline \multicolumn{9}{|c|}{ Number of germinations ( $\%$ in parentheses) } \\
\hline Conditions & $\begin{array}{l}\text { Temp. used for } \\
\text { germination }(\mathrm{C})\end{array}$ & $\begin{array}{l}\text { No. of seeds used } \\
\text { in } 3 \text { replications }\end{array}$ & 7 days & 14 days & 21 days & 28 days & $\begin{array}{c}\text { Total germinated } \\
\text { seeds after } 28 \text { days }\end{array}$ & $\begin{array}{c}\% \text { of germination } \\
\text { after } 28 \text { days }\end{array}$ \\
\hline \multirow{2}{*}{$\begin{array}{l}\text { Non-after } \\
\text { ripened }\end{array}$} & 15 & 30 & $0(0)$ & $7(23.3)$ & $9(30.0)$ & $4(13.3)$ & 20 & $67.0^{\mathrm{cd}}$ \\
\hline & 22 & 30 & $0(0)$ & $13(43.3)$ & $4(13.3)$ & $4(13.3)$ & 21 & $70.0^{\mathrm{c}}$ \\
\hline \multirow{2}{*}{$-20^{\circ} \mathrm{C} \mathrm{AF}$} & 15 & 30 & $0(0)$ & $3(10)$ & $0(0)$ & $0(0)$ & 3 & $10.0^{\mathrm{g}}$ \\
\hline & 22 & 30 & $0(0)$ & $0(0)$ & $0(0)$ & $1(3.3)$ & 1 & $3.3^{\mathrm{h}}$ \\
\hline \multirow{2}{*}{$-20^{\circ} \mathrm{C} \mathrm{AT}$} & 15 & 30 & $0(0)$ & $0(0)$ & $0(0)$ & $0(0)$ & 0 & $0.0^{\mathrm{i}}$ \\
\hline & 22 & 30 & $0(0)$ & $0(0)$ & $0(0)$ & $0(0)$ & 0 & $0.0^{\mathrm{i}}$ \\
\hline \multirow{2}{*}{$0^{\circ} \mathrm{C} A F$} & 15 & 30 & $0(0)$ & $7(23.3)$ & $14(46.7)$ & $0(0)$ & 21 & $70.0^{c}$ \\
\hline & 22 & 30 & $0(0)$ & $12(40)$ & $8(26.7)$ & $1(3.3)$ & 21 & $70.0^{c}$ \\
\hline \multirow{2}{*}{$0^{\circ} \mathrm{C}$ AT } & 15 & 30 & $0(0)$ & $7(23.3)$ & $11(36.7)$ & $2(6.7)$ & 20 & $67.0^{\mathrm{cd}}$ \\
\hline & 22 & 30 & $0(0)$ & $10(33.3)$ & $8(26.7)$ & $2(6.7)$ & 20 & $67.0^{\mathrm{cd}}$ \\
\hline \multirow{2}{*}{$+4^{\circ} \mathrm{C} \mathrm{AF}$} & 15 & 30 & $4(13.3)$ & $16(53.3)$ & $2(6.7)$ & $1(3.3)$ & 23 & $77.0^{\mathrm{b}}$ \\
\hline & 22 & 30 & $7(23.3)$ & $7(23.3)$ & $2(6.7)$ & $2(6.7)$ & 18 & $57.0^{\mathrm{e}}$ \\
\hline \multirow{2}{*}{$+4^{\circ} \mathrm{C} \mathrm{AT}$} & 15 & 30 & $3(10)$ & $16(53.3)$ & $1(3.3)$ & $0(0)$ & 20 & $70.0^{\mathrm{c}}$ \\
\hline & 22 & 30 & $6(20)$ & $9(30)$ & $0(0)$ & $0(0)$ & 15 & $50.0^{\mathrm{f}}$ \\
\hline \multirow{2}{*}{$22 \pm 2^{\circ} \mathrm{C} \mathrm{AF}$} & 15 & 30 & $17(56.7)$ & $4(13.3)$ & $0(0)$ & $0(0)$ & 21 & $70.0^{c}$ \\
\hline & 22 & 30 & $22(73.3)$ & $3(10)$ & $0(0)$ & $0(0)$ & 25 & $83.3^{\mathrm{a}}$ \\
\hline $22 \pm 2^{\circ} \mathrm{C}$ & 15 & 30 & $0(0)$ & $0(0)$ & $0(0)$ & $0(0)$ & 0 & $0.0^{\mathrm{i}}$ \\
\hline AT & 22 & 30 & $0(0)$ & $0(0)$ & $0(0)$ & $0(0)$ & 0 & $0.0^{\mathrm{i}}$ \\
\hline
\end{tabular}

Small letters in superscripts represent significant differences at the level of $5 \%$ according to Tukey Test.

Table 4. Germination rate of 2 month stored mistletoe seeds in different temperature and conditions as determined by germination test at 15 and $22^{\circ} \mathrm{C}$

\begin{tabular}{|c|c|c|c|c|c|c|c|c|}
\hline \multicolumn{9}{|c|}{ Number of germinations (\% in parentheses) } \\
\hline Conditions & $\begin{array}{l}\text { Temp. used for } \\
\text { germination ( }{ }^{\circ} \text { ) }\end{array}$ & $\begin{array}{l}\text { No. of seeds used } \\
\text { in } 3 \text { replications }\end{array}$ & 7 days & 14 days & 21 days & 28 days & $\begin{array}{c}\text { Total germinated } \\
\text { seeds after } 28 \text { days }\end{array}$ & $\begin{array}{l}\% \text { of germination } \\
\text { after } 28 \text { days }\end{array}$ \\
\hline \multirow{2}{*}{$\begin{array}{c}\text { Non-after } \\
\text { ripened }\end{array}$} & 15 & 30 & $0(0)$ & $18(60)$ & $9(30)$ & $0(0)$ & 27 & $90.0^{\mathrm{a}}$ \\
\hline & 22 & 30 & $0(0)$ & $25(83.3)$ & $2(6.7)$ & $0(0)$ & 27 & $90.0^{\mathrm{a}}$ \\
\hline \multirow{2}{*}{$-20^{\circ} \mathrm{C} \mathrm{AF}$} & 15 & 30 & $0(0)$ & $0(0)$ & $0(0)$ & $0(0)$ & 0 & $0.0^{\mathrm{f}}$ \\
\hline & 22 & 30 & $0(0)$ & $0(0)$ & $0(0)$ & $0(0)$ & 0 & $0.0^{\mathrm{f}}$ \\
\hline \multirow{2}{*}{$-20^{\circ} \mathrm{C} \mathrm{AT}$} & 15 & 30 & $0(0)$ & $0(0)$ & $0(0)$ & $0(0)$ & 0 & $0.0^{\mathrm{f}}$ \\
\hline & 22 & 30 & $0(0)$ & $0(0)$ & $0(0)$ & $1(3.3)$ & 0 & $0.0^{\mathrm{f}}$ \\
\hline \multirow{2}{*}{$0^{\circ} \mathrm{C} \mathrm{AF}$} & 15 & 30 & $0(0)$ & $9(30)$ & $11(36.7)$ & $2(6.7)$ & 22 & $73.3^{6}$ \\
\hline & 22 & 30 & $0(0)$ & $16(53.3)$ & $4(13.3)$ & $0(0)$ & 21 & $70.0^{\mathrm{b}}$ \\
\hline \multirow{2}{*}{$0^{\circ} \mathrm{C}$ AT } & 15 & 30 & $0(0)$ & $10(33.3)$ & $9(30)$ & $0(0)$ & 19 & $63.3^{\mathrm{c}}$ \\
\hline & 22 & 30 & $0(0)$ & $13(43.3)$ & $6(20)$ & $0(0)$ & 19 & $63.3^{\mathrm{c}}$ \\
\hline \multirow{2}{*}{$+4^{\circ} \mathrm{C} \mathrm{AF}$} & 15 & 30 & $2(6.7)$ & $10(33.3)$ & $8(26.7)$ & $3(10)$ & 22 & $73.3^{6}$ \\
\hline & 22 & 30 & $9(30)$ & $6(20)$ & $1(3.3)$ & $0(0)$ & 16 & $53.3^{\mathrm{d}}$ \\
\hline \multirow{2}{*}{$+4^{\circ} \mathrm{C} \mathrm{AT}$} & 15 & 30 & $2(6.7)$ & $10(33.3)$ & $1(3.3)$ & $0(0)$ & 13 & $43.3^{\mathrm{e}}$ \\
\hline & 22 & 30 & $9(30)$ & $5(16.7)$ & $0(0)$ & $0(0)$ & 14 & $47.0^{\mathrm{de}}$ \\
\hline \multirow{2}{*}{$22 \pm 2^{\circ} \mathrm{C} \mathrm{AF}$} & 15 & 30 & $0(0)$ & $0(0)$ & $0(0)$ & $0(0)$ & 0 & $0.0^{\mathrm{f}}$ \\
\hline & 22 & 30 & $0(0)$ & $0(0)$ & $0(0)$ & $0(0)$ & 0 & $0.0^{\mathrm{f}}$ \\
\hline $22 \pm 2^{\circ} \mathrm{C}$ & 15 & 30 & $0(0)$ & $0(0)$ & $0(0)$ & $0(0)$ & 0 & $0.0^{\mathrm{f}}$ \\
\hline AT & 22 & 30 & $0(0)$ & $0(0)$ & $0(0)$ & $0(0)$ & 0 & $0.0^{\mathrm{f}}$ \\
\hline
\end{tabular}

Small letters in superscripts represent significant differences at the level of $5 \%$ according to Tukey Test.

weeks. Similar trends of germination were also observed in two months stored seeds where the maximum germination was 
$33.3 \%$ in AF within two weeks. However, in AT conditions at $4{ }^{\circ} \mathrm{C}, 30 \%$ germination was observed within first week. The germination patterns of seeds stored at room temperature were varied. The maximum germination was found within first week in the seeds stored for one month with $73.3 \%$ and $56.7 \%$ in the germinator at $22 \& 15^{\circ} \mathrm{C}$ respectively in $\mathrm{AF}$ conditions.

\section{Effect of chemical and mechanical scarification on seed gemination}

Scarification (chemical, mechanical or thermal method) has been used to break seed dormancy. It increases seed coat permeability to allow water or gases exchange and encourage germination (Crocker and Barton 1953). According to our data (Table 5 A \& B), chemical scarification of the seeds showed enhanced germination rate $(93 \%)$ as compared to the nonscarified seed, but the mechanical methods (sand scarification followed by $12 \mathrm{hrs}$ incubation at $38^{\circ} \mathrm{C}$ ) failed to stimulate germination (63.3\%). The scarified and non-scarified seeds showed similar pattern of germination, where the maximum rate was observed within two weeks in the range of 40 to $43.3 \%$. The sand scarification seeds showed lower survival rate with $70 \%$ compared to $100 \%$ in non-scarified seeds. In previous report, Wicker (1962) showed that chemicals like hydrogen peroxide can stimulate germination of Arceuthobium spp. However, Scharpf (1970) failed to stimulate germination by using sulphuric acid in $A$. occidental (type of mistletoe).

\section{Discussion}

Our study showed that the temperature played an important role on the germination of mistletoe. The stratified seeds at different temperatures $\left[-20,0,4^{\circ} \mathrm{C}\right.$ and room temperature $(22 \pm$ $2^{\circ} \mathrm{C}$ )] and conditions (AF \& AT) showed different germination pattern when allowed to grow in two constant temperature regimes of 15 and $22^{\circ} \mathrm{C}$. In this experiment, we followed the international seed testing rules (ISTA, 1999) according to which the seed germination was defined as the appearance of a radicle at least of $2 \mathrm{~mm}$ long, therefore, in our experiment, radicle appearance of upto $2 \mathrm{~mm}$ long was monitored every week for 4 weeks and considered as germinated seeds.

According to the data, seeds kept for two months in natural condition showed significantly higher percentage (above $90 \%$ ) of germination than that of freshly harvested seeds (average $70 \%$ ). This lower percentage of germination in freshly harvested seeds could be due to lack of full maturation of some seeds during harvesting time.

In our research, the mistletoe seeds stored at freezing

Table 5. Survivability (A) and Germination rate (B) of mistletoe seeds after chemical and mechanical scarification

\begin{tabular}{|c|c|c|c|c|c|c|c|}
\hline & (A) & & & nber of se & survived ( & in parentheses) & \\
\hline Conditions & $\begin{array}{l}\text { No. of seeds used } \\
\text { in } 3 \text { replications }\end{array}$ & 7 days & 14 days & 21 days & 28 days & \multicolumn{2}{|c|}{ Total $\%$ of survival rate after 28 days } \\
\hline $\begin{array}{c}\text { Control } \\
\text { (no treatment) }\end{array}$ & 30 & $30(100)$ & $30(100)$ & $30(100)$ & $30(100)$ & \multicolumn{2}{|c|}{$100^{\mathrm{a}}$} \\
\hline $\begin{array}{c}\mathrm{HCl} \\
\left(0.01 \mathrm{~N} 12 \mathrm{hrs} 38^{\circ} \mathrm{C}\right)\end{array}$ & 30 & $30(100)$ & 28(93.3) & $28(93.3)$ & $28(93.3)$ & \multicolumn{2}{|c|}{$93^{\mathrm{b}}$} \\
\hline $\begin{array}{l}\text { Sand Scarification } \\
\left(12 \mathrm{hrs} 38^{\circ} \mathrm{C}\right)\end{array}$ & 30 & $27(90)$ & $23(76.7)$ & $21(70)$ & $21(70)$ & \multicolumn{2}{|c|}{$70^{\mathrm{c}}$} \\
\hline & (B) & \multicolumn{6}{|c|}{ Number of germinations ( $\%$ in parentheses) } \\
\hline Conditions & $\begin{array}{l}\text { No. of seeds used } \\
\text { in } 3 \text { replications }\end{array}$ & 7 days & 14 days & 21 days & 28 days & $\begin{array}{c}\text { Total germinated } \\
\text { seeds after } 28 \text { days }\end{array}$ & $\begin{array}{c}\% \text { of germination } \\
\text { after } 28 \text { days }\end{array}$ \\
\hline $\begin{array}{c}\text { Control } \\
\text { (no treatment) }\end{array}$ & 30 & $0(0)$ & $13(43.3)$ & $4(13.3)$ & $4(13.3)$ & 21 & $70^{\mathrm{b}}$ \\
\hline $\begin{array}{c}\mathrm{HCl} \\
\left(0.01 \mathrm{~N} 12 \mathrm{hrs} 38{ }^{\circ} \mathrm{C}\right)\end{array}$ & 30 & $0(0)$ & $13(43.3)$ & $9(30)$ & $5(16.7)$ & 28 & $93.3^{\mathrm{a}}$ \\
\hline $\begin{array}{l}\text { Sand Scarification } \\
\left(12 \mathrm{hrs} 38^{\circ} \mathrm{C}\right)\end{array}$ & 30 & $0(0)$ & $12(40)$ & $3(10)$ & $3(10)$ & 18 & $63.3^{\mathrm{c}}$ \\
\hline
\end{tabular}


temperature $\left(0^{\circ} \mathrm{C}\right)$ showed similar results as that of non-afterripened seeds. However, the seeds stored at $-20^{\circ} \mathrm{C}$ showed lower survival and germination percentages that could be due to intracellular freezing injury, where the seed tissues might get injured by causing membrane destruction, dehydration, lipid phase separation (Burke et al., 1976). During our research it was observed that the prolonged storage of seeds at room temperature was contaminated by fungal spores, which also cause the reduction in germination rate. As it was reported that the fungal spores cause seed discoloration, death of ovules and embryos resulting in the decline in survival and germination rate of seeds (Christensen, 1957). The sand scarified seeds showed lower survival rate with $70 \%$ compared to $100 \%$ in non-scarified seeds. In other study by Scharpf (1970) also found that the seeds stratified in sand lost viability rapidly because of deterioration by mold fungi.

The scarified seeds showed significantly higher rate of germination than that of the non-scarified seeds, which could be due to the removal of some chemicals (viscin) of the seeds that prevent germination during hydrochloric acid $(0.01 \mathrm{~N}$ $\mathrm{HCl})$ scarification. In previous studies, Crocker and Barton (1953); and Beckman and Roth (1968) also found that fleshy coating of some seeds or viscin layer of mistletoe seeds could prevent germination.

In conclusion, higher percentage $(90 \%)$ of germination and survivability $(100 \%)$ of two months stored seeds in natural condition confirmed that mistletoe does not need after ripened treatment in freezing temperature to promote germination. In a previous research, Scharpf and Parmeter (1962) also found that seeds of $A$. occidentale (kind of mistletoe) do not need freeze treatment to support germination. According to this research, if $L$. tanakae seeds need to preserve, 0 to $4^{\circ} \mathrm{C}$ is preferred for short (less than one month) duration in $\mathrm{AF}$ conditions where the survivability and germination rate ranged between 83.3 to $90 \%$ and 67 to $77 \%$ respectively. Our research also showed that the storage of L. tanaka seeds in freezing temperatures at $-20^{\circ} \mathrm{C}$ and in room temperature either in AT or AF conditions caused the loss of survival and germination rate. On the other hand, the chemical scarification $(0.01 \mathrm{~N}$ $\mathrm{HCl}$ incubation for $12 \mathrm{hrs}$ ) method was proven more effective to enhance germination percentage of $L$. tanakae. Regarding the temperature regime, $22^{\circ} \mathrm{C}$ showed early germination of mistletoe seeds in vitro.

\section{Acknowledgement}

This research was supported by Export Promotion Technology Development Program, Ministry of Agriculture, Food and Rural Affairs. We also thanks to the Institute of Bio-Science \& Biotechnology, Kangwon National University for providing research facilities.

\section{References}

Beckman, L.M. and L.F. Roth. 1968. The influence of temperature on longevity and germination of seed of dwarf mistletoe. Phytopathology 58:147-150.

Burke, M.J., L.V. Gusta, H.A. Quamme, C.J. Weiser and P.H. Li. 1976. Freezing and injury in plants. Ann. Rev. Plant Physiol. 27:507-528.

Christensen, C.M. 1957. Deterioration of stored grains by fungi. Botanical Rev. 23:108-134.

Crocker, W. and L.V. Barton. 1953. Physiology of Seeds; an introduction to the experimental study of seed and germination problems. Waltham, Mass, Chronica Botanica Co., Harvard (18 ${ }^{\text {th }}$ ed.), Chicago, USA. p. 267.

Calvin, C.L. and C.A. Wilson. 1998. The haustorium system in African Loranthaceae. Polhill, R. and D. Weins (eds.), The Mistletoes of Africa. Royal Botanical Gardens, Kew, London, UK. pp. 17-36.

Huaxing, Q., C.H. Hsing, K.H. Xing and M.G. Gilbert. 2003. Loranthaceae. Flora of China. 5:220-239.

International Seed Testing Association (ISTA) (1999). International rules for seed testing. Seed Science and Technology 27, Supplement. p. 333.

Kim, C.S., S.Y. Kim., B.Y. Sun and J.S. Yi. 2013. A review of the taxonomic and ecological characteristics of Korean mistletoe types (Viscum, Korthalsella, Loranthus and Taxillus). Korean J. Plant Taxon. 43:81-89.

Kim, Y.K., Y.S. Kim, S.U. Choi and S.Y. Ryu. 2004. Isolation of flavonol rhamnosides from Loranthus tanakae and cytotoxic effect of them on human tumor cell lines. Arch. Pharma. Res. 27:44-47.

Lee, S.G., S.H. Lee and H. Kang. 2010a. Effect of storage germination duration, medium and viscin on in vitro seed germination in endangered species, Loranthus tanakae. Korean J. For. Soc. 99:618-624.

Lee, S.G., S.H. Lee, K.W. Park, Y.H. Kwon and H. Kang. 2010 b. 
Effects of host tree species, temperature and humidity on ex-vitro seed germination in endangered species of Loranthus tanakae. Korean J. For. Soc. 99:871-877.

Lee, B.D. and B.S. Park. 2009. Anatomical characteristics of Korean mistletoe (Viscum album var. coloratum (Kom.) Ohwi) stem. Korean J. Plant Res. 22:287-292.

Scharpf, R.F. 1970. Seed viability, germination and radicle growth of dwarf mistletoe in California. Berkeley, Calif.
Pacific SW. Forest \& Range Exp. Sta., USDA. Forest Serv. Res. Paper PSW-59.

Scharpf, R.F. and J.R. Parmeter. 1962. The collection, storage and germination of seeds of dwarf mistletoe. J. Forestry 60:551-552.

Wicker, Ed. F. 1962. Rapid germination as a viability test for seed of Arceuthobium spp. Phytopathology 52:757.

(Received 30 April 2014 ; Revised 2 June 2014 ; Accepted 12 June 2014) 